\title{
HALOTOLERANT AND CHAOTOLERANT MICROFUNGI FROM LITTORAL ANCHIALINE CAVES GOLUBINKA AND MEDOVA BUŽA (CROATIA)
}

\author{
Andrzej Chlebicki ${ }^{1, c}$ and Natalia Jakus ${ }^{2}$
}

\begin{abstract}
Rock-inhabiting fungi were isolated for rock walls in Golubinka and Medova Buža littoral anchialine caves in Croatia and tested for their halotolerance. Isolates were identified as Cladosporium psychrotolerans, C. delicatulum, Mucor circinelloides, Rhizopus stolonifer, Aureobasidium pullulans var. pullulans, and Talaromyces diversus. Of them, T. diversus appears most resistant to cosmotropic $(\mathrm{NaCl})$ and chaotropic $(\mathrm{KCl})$ salts. It was also the most common species isolated from rock walls. Despite the negative influence of salinity on acid production, we propose that some fungal strains can be recognized as active agents in carbonate dissolution and as good competitors on rocks in saline environments. Anchialine caves can be a refugium for unique halotolerant fungi.
\end{abstract}

\section{Introduction}

The coastal sea area including islands of the Republic of Croatia is about $33,200 \mathrm{~km}^{2}$. In comparison with the area of the eastern Adriatic territorial waters, the groups of islands covers a large area, being divided into several groups (Duplančić et al. 2004). The Adriatic Carbonate Platform (AdCP), is covered by Palaeozoic-Triassic deposits, Late Cretaceous-Palaeogene flysch, or Neogene and Quaternary deposits (Vlahović et al. 2005). The major types of rocks that build AdCP are freshwater or brackish and foraminiferal limestones; mudstones; marles; and silicoclastics. The region was changed by several tectonic events during the Palaeogene, Oligocene, and Miocene (Vlahović et al. 2005). Palaeogene compressional tectonics strongly influenced the area by faults oriented south-west to north-east. This direction is typical for this part of the karst terrain in the region, and it is often called Dinaric strike or even Dinaric karst. Rocks are eroded among zones of weakness by the hydraulic power of the waves and the abrasive force of suspended particles in water. Corrosion and bioerosion also have a significant influence on coastal shape in the mixing zone of fresh and sea water (Pikelj and Juračić 2013), and as a result, sea caves are formed. Among other karst features on islands are panholes, channels and furrows, uvalas and others. More than 235 submerged caves and pits have been noted along the Croatian coast and islands (Surić et al. 2010).

Anchialine cave, are the cave systems occurring in coastlines that are flooded with seawater. Pohlman et al. (1997) presents the first extensive description of the ecological and biogeochemical relationships of the anchialine cave ecosystem. They hypothesized that organic matter supporting the anchialine ecosystem would be: algal detritus transported by groundwater flow from the cenotes; soil particulates percolating from the tropical forest soil through the cracks and fissures of the limestone bedrock into the caves; coastal-borne particulate organic matter transported into the cave systems with tidally-exchanged seawater; and the potential for chemoautotrophic production of organic matter by bacteria. Only soil particulates from the forest did not occur in our caves due to lack of forest cover in the rock massive. Instead of forest particulates, small and scattered deposits of bat guano were found in both investigated caves.

There are many papers dealing with fungi in caves and mines (Nováková 2009; Nováková et al. 2012, Ogórek et al. 2013). A worldwide review of Fungi and Slime molds in caves was provided by Vanderwolf et al. (2013). Fungi and Slime molds are heterotrophic, using organic carbon for carbon and energy. Mineral pores and cavities, cracks and fissures are inhabited by cryptoendoliths (Ehrlich 1981; Sterflinger 2000; Burford et al. 2003). Rock-inhabiting fungi (RIF) dissolve minerals by excretion of enzymes, metal-binding ligands, siderophores, and acids. They transform minerals by dissolution and secondary mineral formation (Gadd 1993, 1999; Verrecchia 2000; Burford et al. 2003; Barton 2006; Barton and Northup 2007). Fungi are biosorbents for metal cations, such as $\mathrm{Cd}, \mathrm{Cu}, \mathrm{Zn}, \mathrm{Au}, \mathrm{Ni}, \mathrm{Fe}, \mathrm{Ag}$ and others (Tobin 2001). The presence of melanin and chitin in fungal cells increases the rate of biosorption (Gadd and Mowll 1985). Investigations of fungi in marine sediments and organisms (sponges) have also been performed (Sponga et al. 1999).

The salinity of Mediterranean sea water ranges from 38-39\%. There are solids such as cosmotropic $\mathrm{NaCl}(86 \%$ of total solids), as well as $\mathrm{Mg}, \mathrm{S}, \mathrm{Ca}, \mathrm{K}, \mathrm{Br}, \mathrm{C}, \mathrm{Sr}$ and $\mathrm{B}$ (Masuma et al. 2001). Cosmotropic salts are stabilizing salts, such as $\mathrm{NaCl}$ and $\mathrm{KCl}$, that stabilize proteins, whereas chaotropic salts are recognized as destabilizing salts like $\mathrm{MgCl}_{2}$ that unfold proteins and increase solubility of hydrophobic chemicals.

\footnotetext{
${ }^{1}$ W. Szafer Institute of Botany, Polish Academy of Sciences, Lubicz 46, 31-512 Cracow, Poland

${ }^{2}$ AGH University of Science and Technology; Faculty of Geology, Geophysics and Environmental Protection; al. Mickiewicza 30, 30-059 Cracow, Poland

c Corresponding author: a.chlebicki@botany.pl
} 
The stimulation of $\mathrm{CO}_{2}$ production by low salt concentrations $(1 \% \mathrm{NaCl})$ has been confirmed by numerous experiments with yeast (Speakman et al. 1928). Marine fungi can grow abundantly in a medium with $4 \% \mathrm{NaCl}$, whereas the same $\mathrm{NaCl}$ concentration suppressed growth of terrestrial fungi (Masuma et al. 2001).

We were interested in the occurrence of rock-inhabiting fungi (RIF) that can decompose natural rocks in a cave. We tested acidification of media by isolating fungi that can indicate the possibility of dissolution of rock minerals. We also tested the ability of isolated fungi for their ability to grow in dissolved cosmotropic salt $(\mathrm{NaCl})$ and chaotropic salt $\left(\mathrm{MgCl}_{2}\right)$.

\section{Methods}

\section{Study Sites}

Two anchialine caves were chosen for investigation: Medova Buža from Rab Island and Golubinka from Dugi Otok. Dugi Otok (Long Island in English) and Rab Island belong to the megageomorphologic region of the Dinaric Mountain Belt, specifically to the macrogeomorphologic region of central Dalmatia with archipelago (Bognar 2001).

Dugi Otok is the largest and easternmost of the Zadarian Islands and derives its name from its distinctive shape. The semi-dark Golubinka Cave (Fig. 1) located on this island is one of 57 speleological features observed on Dugi Otok Island (Dzaja 2003). This $100 \mathrm{~m}$ long cave with an entrance accessible from the sea is situated on the steep southern slopes near Brbinjšćica Bay. Its main development extends to the north. The rock composition of the cave is dominated by Mesozoic carbonates. The Golubinka Cave is inhabited by many bats; among them are approximately 2000 Myotis emarginatus and approximately 1000 Rhinolophus ferrumequinum as well as Tadarida teniotis and Plecotus austriacus (Pavlinič et al. 2010). Fifty species of Porifera occur on the submerged rock walls. The bottom of the cave corridor is submerged; moreover, the lower parts of the cave walls are seasonally submerged or splashed by sea water such that bat guano and other organic detritus cannot be deposited in these places. Only small deposits can be attached to the upper part of cave walls.

Medova Buža Cave (107 m long) is located near Lopar on Rab Island (Fig. 1). It is composed of four rooms; only the first was investigated by us. This cave stretches approximately $60 \mathrm{~m}$ into Rab Island and is connected to the sea. The

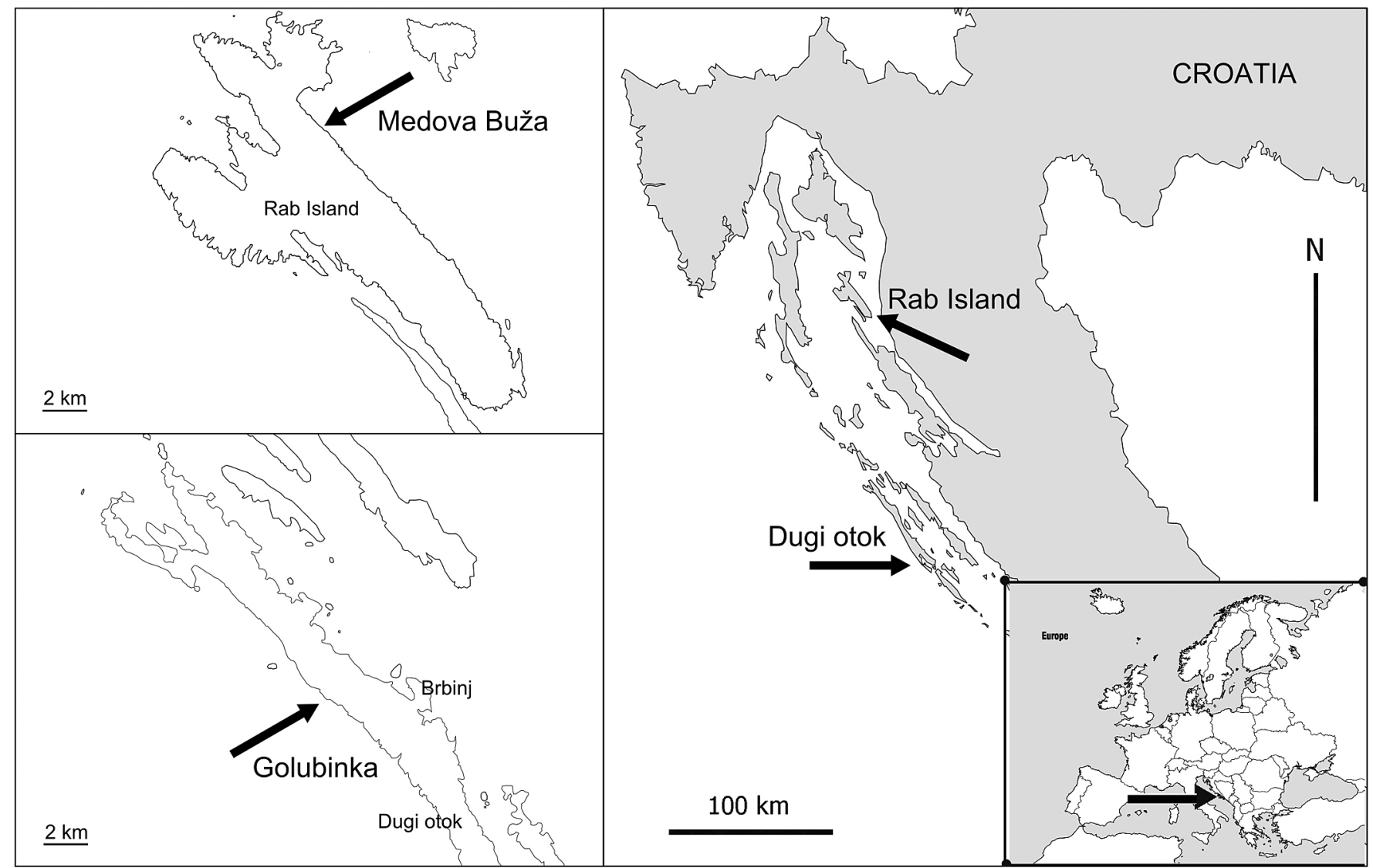

Figure 1. Anchialine caves in Croatia: A, B - Golubinka Cave on Dugi Otok Island; C, D - Medova Buža Cave on Rab Island. 
entrance is $4 \mathrm{~m}$ below the surface. The bottom of this cave corridor is also submerged. The cave is inhabited by 4270 bats (Inf.Eurobats.Ac.19 2004) as Miniopterus schreiberii, M. emarginatus and Rhinolophus euryale.

Dugi Otok Island is made of carbonates of the Cretaceous age that have been deposited in deeper environments compared to carbonates from most of the other localities in coastal Croatia. These are commonly micritic-type limestones, occasionally with evidence of deposition from mass-flow and slope instabilities (Perica et al. 2004).

The oldest exposed rocks on Rab Island are Cretaceous carbonates, represented mainly by foraminiferal limestones, which are overlain by Eocene carbonates and clastics (limestones, marls and sandstones). The contact between Cretaceous and Eocene deposits is characterised by unconformity and occurrences of bauxite (Marjanac and Marjanac 2007). Important influences also include abrasion, corrosion in the mixing zone of water and bioerosion (Pikelj and Juračić 2013), especially in weak zones of cliffs.

\section{Material Collection}

Medova Buža: material was collected May 25, 2015 from its entrance; Golubinka Cave: material was collected June 2, 2015 from rock walls inside the cave. We collected chips of rocks approximately $150 \mathrm{~cm}$ above sea level (Fig. 2) because the lower parts of the cave walls were seasonally submerged or splashed by sea water. We used an ethanol flame-sterilized metal hammer to chip off cave rock walls. All collected materials were placed in sterile plastic boxes and refrigerated. After six days material was transported to Poland and placed in an incubator at $10^{\circ} \mathrm{C}$. In the laboratory the samples were mechanically crushed into small rock fragments.

Strain isolation Strains were isolated on RBC (Rose-Bengal Chloramphenicol, Merck KgaA) medium. Afterward, PDA (Potato Dextrose Agar, Merck KgaA) and MEA (Malt Extract Agar, Merck KgaA) media were used. At the beginning, several additions of $\mathrm{NaCl}$ to the MEA media were used: $1.7 \%, 3.4 \%$ and $6.8 \% \mathrm{NaCl}$. Strains put in $\mathrm{RBC}$ were incubated at $10^{\circ} \mathrm{C}$; other material was stored at room temperature.

\section{Morphology}

The morphological characters of the living fungi were examined in water and in lactophenol cotton blue using light microscopy (Nikon SMZ 1500, Nikon Labophot 2 and Nikon Eclipse 800) equipped with a digital camera. For identification of fungi we used taxonomic guides and articles (Bensch et al., 2010, 2012; Owczarek-Kościelniak et al. 2016; Schipper 1976, 1984; Yilmaz et al., 2014; Zalar et al. 2007). Colony diameters were measured with a ruler.

\section{Halotolerance}

Halotolerance (ionic $\mathrm{NaCl}$ ) and chaotolerance (ionic $\mathrm{MgCl}_{2}$ ) were identified from YMA (Yeast Salt Agar, Sigma-Aldrich) (Jančič et al. 2015). Conidia were suspended in $0.9 \% \mathrm{NaCl}$ and $0.05 \%$ agar and were point-inoculated in triplicate on each plate onto prepared media in $9 \mathrm{~cm}$ Petri dishes incubated at room temperature for 7, 14, and 28 days. Ionic $\mathrm{MgCl}_{2}$ at 4, 9, 15, 16 and $17 \%$ and ionic $\mathrm{NaCl}$ at 10,12,14, 16, 18, 20, 24 and $28 \%$ were used in six replicates in each combination. Colony diameters were read after 14 days. We used the halotolerant strain of Wallemia mellicola Jancic, Nguyen, Seifert \& Gunde-Cimerman (Jančič et al. 2015) for comparison of its halotolerance with those of isolated species.

\section{Acidity}

For experiments with $\mathrm{pH}$ indicators, we used YMA medium with 20 drops dibromothymolsulphonephthalein and 10 drops of $10 \% \mathrm{KOH}$. Such media were green at the beginning $(\mathrm{pH}=7)$ and turned yellow with acidity. A change in medium color from green to yellow indicates production and secretion of acids by these fungi.

\section{Results}

\section{Fungi Isolated from Rocks in the Caves}

\section{Cladosporium delicatulum}

According to Bensch et al. (2012), this species has been isolated from indoor air, building materials, dead leaves, fruits and tubers. It is a common and widely distributed hyphomycete, clustered as a sister to Cladosporium cladosporioides (Bensch et al. 2010).

\section{Cladosporium psychrotolerans}

This species was isolated from hypersaline water in Slovenia (Zalar et al. 2007). It was also reported from indoor environments and on plant leaves (Bensch, et al., 2012). Typical strains have a maximum salt concentration tolerance of $17 \%$. We have viable cultures growing on PDA with $16 \%$ salt concentration (Fig. 3 ).

\section{Mucor circinelloides}

This species was present in all plates and often overgrowing other fungal species. The fungus occurs on fruits, as well as in soil; compost; guts and dung of animals; pellets; river water and hypersaline water of saltpans; air; decaying plant material; and living animals, such as Troglophilus neglectus (Gunde-Cimerman et al. 1998), Ornithorhynchus 

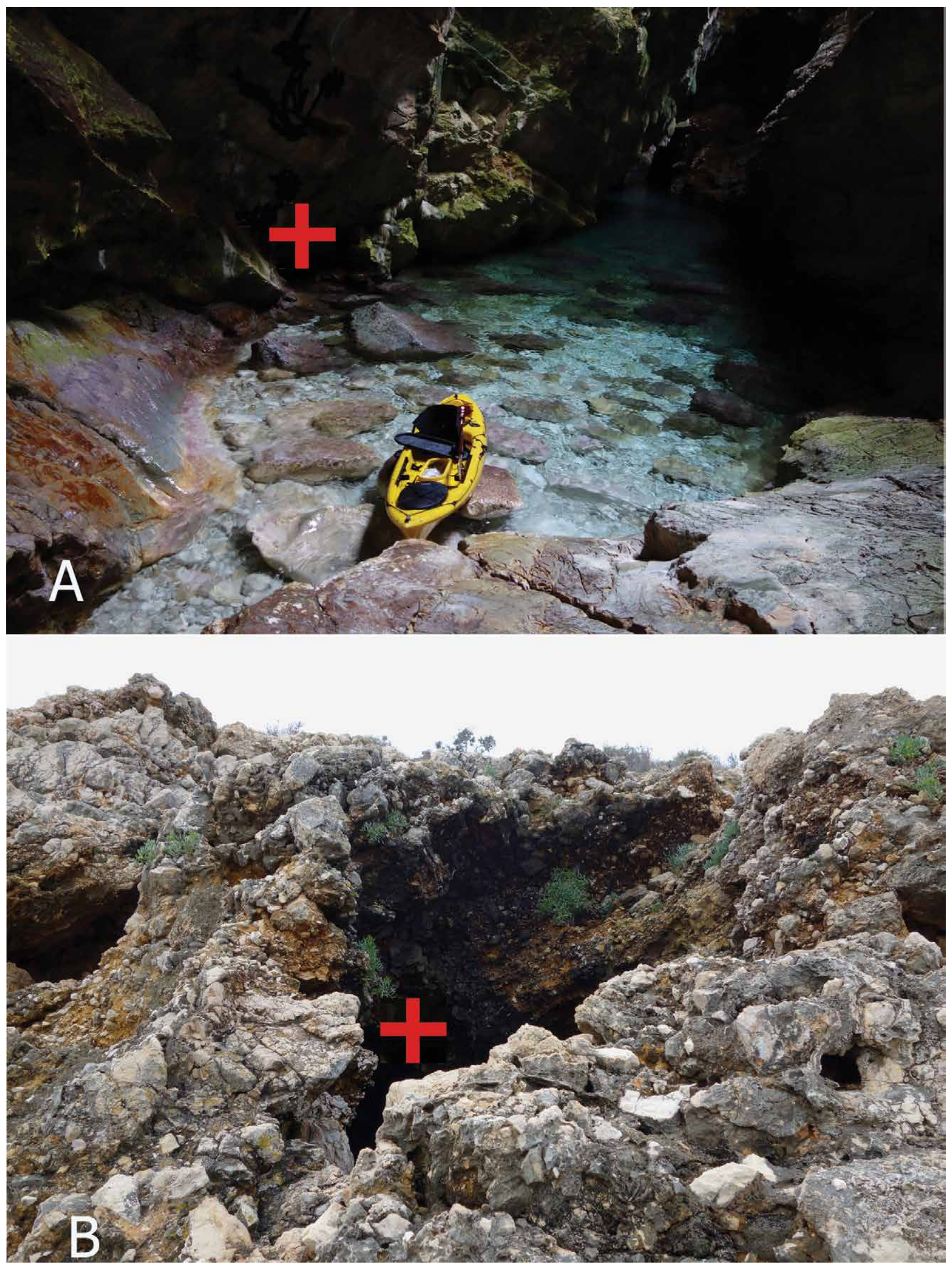

Figure 2. Anchialine caves in Croatia: A - central part of Golubinka Cave under window of rock vault, inside Provler Trident 11 kayak (80 $\mathrm{cm}$ wide); B - entrance of Medova Buža Cave. Sample collection sites marked. 


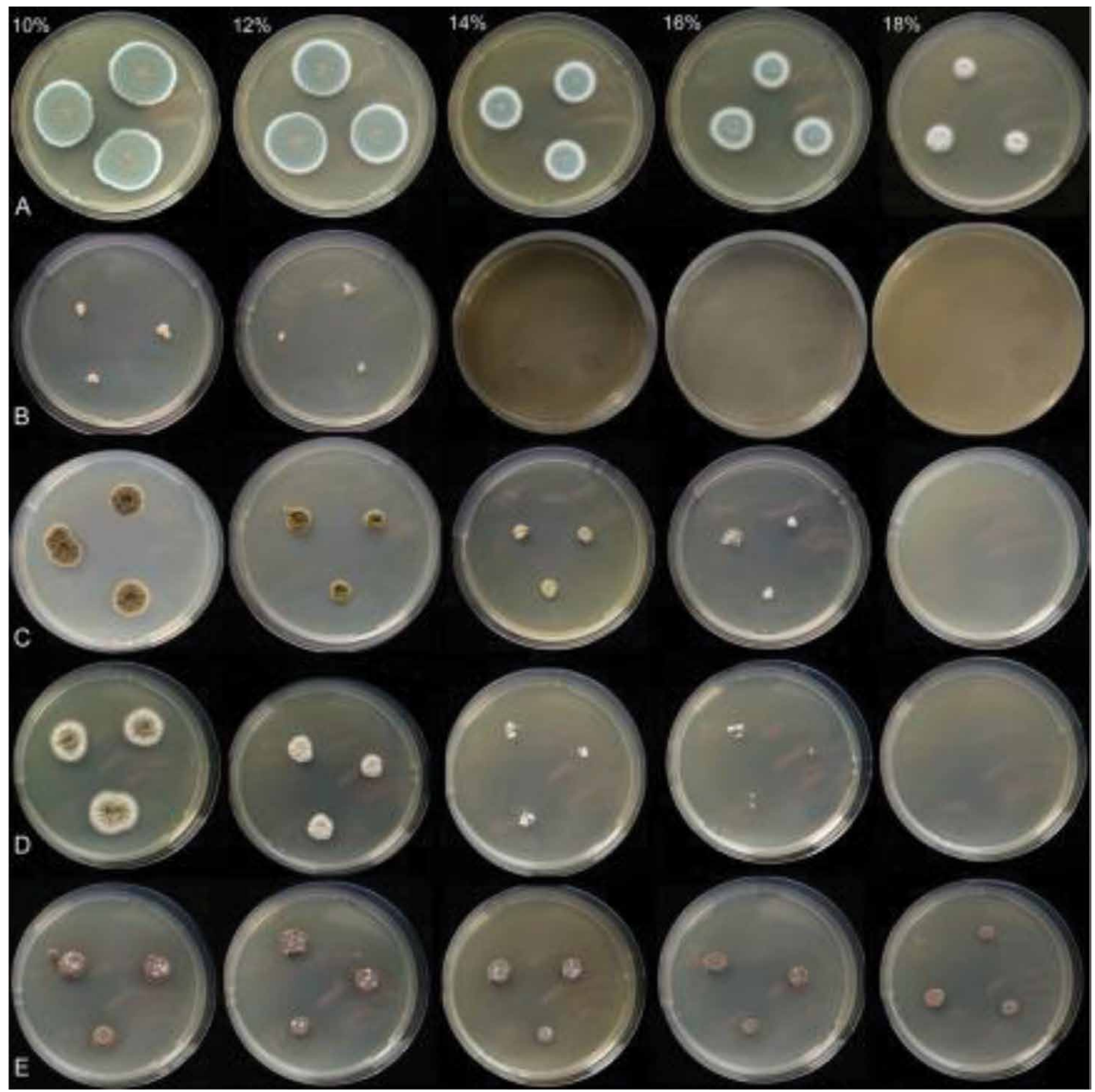

Figure 3. Halotolerance: A - Talaromyces diversus; B - Aureobasidium pullulans; C - Cladosporium delicatulum; D - Cladosporium psychrotolerans; $\mathrm{E}$ - Wallemia mellicola. Concentration of $\mathrm{NaCl}$ from left to right: $10 \%, 12 \%, 14 \%, 16 \%$, and $18 \%$.

anatinus (Stewart et al. 1999) and Pelteobagrus fulvidraco (Ke et al. 2009). The species is reported to infect other animals (cattle, swine, and fowl) in anaerobic condition (Lübbehüsen et al. 2003). The fungus has a growth optimum of approximately $30^{\circ} \mathrm{C}$ (Michailides 1991), and its upper temperature limit is $38^{\circ} \mathrm{C}$. It has a yeast-like growth phase in an anaerobic atmosphere and in the presence of $30 \% \mathrm{CO}_{2}$ (Lübbehüsen et al. 2003). It is a carotene producer.

\section{Rhizopus stolonifer}

A single colony was isolated from an RBC plate. It is very common species, normally found at the entrance and interior of caves (Ogórek et al. 2014). 


\section{Aureobasidium pullulans var. pullulans}

Colonies are mucoid and pink, hyphae septate and spores one-celled. Our strain was isolated from a single plate. The species appeared sensitive to high salt concentrations, however, other strains of this species are able to grow at relatively high concentrations of $\mathrm{NaCl}$ (Zajc et al. 2014). Our strain (unpublished data) has identical ITS sequence as a fungus isolated from roots of Juncus trifidus (see Owczarek-Kościelniak et al. 2016).

\section{Talaromyces diversus}

This species belongs to the section Trachyspermi Yaguchi \& Udagawa (Yilmaz et al. 2014). Novakova (2009) isolated similar species - Talaromyces flavus (Klöcker) Stolk \& Samson (syn. T. vermiculatus) from earthworm casts in the Dominica cave system in Slovakia. Nováková et al. (2012) noted it from timber in the abandoned Jeroným uranium mine at Jáchymov. Moreover, the fungus can synthesise colloidal silver nanoparticles (Ganachari et al. 2012) and produce mitorubrinic acid (Yilmaz et al. 2014).

\section{Halotolerance}

It is evident that some isolates are well accommodated to saline environments. Talaromyces diversus is the most resistant halotolerant species (Table 2). Also, both species of Cladosporium are well adapted to saline environments. At the same time, T. diversus is also the most resistant strain to chaotropic salt (Table 3 ).

Table 1. Fungi isolated from two littoral anchialine caves in Croatia.

\begin{tabular}{lc}
\multicolumn{1}{c}{ Fungus Name } & $\begin{array}{c}\text { Golubinka } \\
\text { Cave }\end{array}$ \\
\hline Aureobasidium pullulans var. pullulans (de Bary \& Löwenthal) G. Arnaud & - \\
Cladosporium psychrotolerans Zalar, de Hoog \& Gunde-Cimerman & + \\
Cladosporium delicatulum Cooke & + \\
Mucor circinelloides Tiegh. & - \\
Rhizopus stolonifer (Ehrenb.) Vuill. & + \\
Talaromyces diversus (Raper \& Fennell) Samson, Yilmaz \& Frisvad & + \\
\hline
\end{tabular}

Note: + indicates presence of fungus in the cave.

- indicates absence of fungus in the cave.

Table 2. Halotolerance of fungi isolated from two anchialine caves in Croatia. (Wallemia mellicola added for comparison.)

\begin{tabular}{lccccccc}
\hline \multicolumn{1}{c}{ Species } & $10 \% \mathrm{NaCl}$ & $12 \% \mathrm{NaCl}$ & $14 \% \mathrm{NaCl}$ & $16 \% \mathrm{NaCl}$ & $18 \% \mathrm{NaCl}$ & $20 \% \mathrm{NaCl}$ & $24 \% \mathrm{NaCl}$ \\
\hline Aureobasidium pullulans & + & + & \pm & - & - & - & - \\
Cladosporium delicatulum & + & + & + & \pm & - & - & - \\
Cladosporium psychrotolerans & + & + & + & \pm & - & - & - \\
Mucor circinelloides & + & - & - & - & - & - & - \\
Talaromyces diversus & + & + & + & + & + & + & \pm \\
Wallemia mellicola & + & + & + & + & + & + & - \\
\hline
\end{tabular}

Note: + indicates that fungus can grow in these media with salt solution.

- indicates fungus growth inhibition by salt solution.

Table 3. Chaotolerance of fungi isolated from two anchialine caves in Croatia. (Wallemia mellicola added for comparison.)

\begin{tabular}{lcccc}
\hline \multicolumn{1}{c}{ Species } & $\mathbf{9} \% \mathrm{MgCl}_{2}$ & $\mathbf{1 5} \% \mathrm{MgCl}_{2}$ & $\mathbf{1 6} \% \mathrm{MgCl}_{2}$ & $\mathbf{1 7} \% \mathrm{MgCl}_{2}$ \\
\hline Aureobasidium pullulans & + & - & - & - \\
Cladosporioum delicatulum & + & - & - & - \\
Cladosporium psychrotolerans & + & - & - & - \\
Mucor circinelloides & \pm & - & - & - \\
Talaromyces diversus & + & + & + & - \\
Wallemia mellicola & + & + & \pm & - \\
\hline
\end{tabular}

Note: + indicates presence of fungus in the cave.

- indicates absence of fungus in the cave. 
Table 4. Acid production by fungi isolated from two anchialine caves in Croatia. (+ indicates extent of colour change on PDA medium with dibromothymolsulphonephthalein indicator.)

\begin{tabular}{|c|c|c|c|c|}
\hline Fungus & $0 \% \mathrm{NaCl}$ & $3.4 \% \mathrm{NaCl}$ & $5 \% \mathrm{NaCl}$ & $10 \% \mathrm{NaCl}$ \\
\hline Aureobasidium pullulans & + & + & + & - \\
\hline Cladosporium delicatulum & ++ & + & + & - \\
\hline Cladosporium psychrotolerans & ++ & + & + & + \\
\hline Mucor circinelloides & - & - & - & - \\
\hline Talaromyces diversus & ++++ & +++ & ++ & + \\
\hline Wallemia mellicola & ++ & + & - & - \\
\hline
\end{tabular}

Note: ++++ indicates bigger size of color change.

+++ indicates medium size of color change.

++ indicates small size of color change.

+ indicates very small size of color change.

- indicates lack of acid production.

\section{Chaotolerance}

Aureobasidium pullulans, both species of Cladosporium, and Mucor circinelloides were inhibited by $15 \% \mathrm{MgCl}_{2}$. Whereas Talaromyces diversus and Wallemia mellicola were the most resistant strains to chaotropic salt (Table 3).

\section{Acid Production}

We tested isolated strains for acid production in media with dibromothymolsulphonephthalein, $(\mathrm{pH} 7)$. Species such as Cladosporium delicatulum, T. diversus, and Aureobasidium pullulans var. pullulans alter pH in PDA plates (Table 4). However, acid production and secretion in Mucor circinelloides was absent. Colony shape of $A$. pullulans var. pullulans changes with increasing salinity of YMA medium. Margins of colonies in the absence of $\mathrm{NaCl}$ were fimbriate, whereas other colonies influenced by $\mathrm{NaCl}$ contained slightly undulate to entire margins $(10 \% \mathrm{NaCl})$.

\section{Discussion}

Both caves investigated are littoral anchialine caves. Typical anchialine caves connect sweet water from the sea and form a distinct boundary layer between them. Soil particulates mentioned by Pohlman et al. (1997) percolating from the tropical forest soil into the caves did not occur in our caves due to a lack of forest cover on rock massifs. Instead of forest particulates, bat guano was found in both caves.

Bat guano contains many phosphates and nitrates that can dissolve sandstone (Hosono et al. 2006). However, the lower parts of cave walls are seasonally submerged or splashed by sea water. Also, drops of the marine water can reach higher-located rocks so surfaces will be covered by various concentrations of diluted $\mathrm{NaCl}$ and small amounts of other solids. Among fungi isolated on rocks in our caves were coprophilous species from the genera Aspergillus, Mucor and Rhizopus. These fungi did not grow on media with highly concentrated $\mathrm{NaCl}$ and $\mathrm{MgCl}_{2}$. However, species of Cladosporium, A. pullulans and T. diversus grown in media with $14 \%$ concentrations of $\mathrm{NaCl}$ (Table 2) can be recognized as halotolerant fungi (see Cantrell et al. 2006). Some species of fungi belonging to the genus Cladosporium have been described from hypersaline environments (Zalar et al. 2007), among them C. psychrotolerans, noted by us in Golubinka Cave. Fungal deterioration of rocks can be made by acid excretion. Talaromyces diversus produces mitorubrinic acid (Yilmaz et al. 2014), which can dissolve limestone rocks. However, salinity agents appear to decrease acid production and excretion (Table 4). According to Harrison et al. (2015), differences in salinity influence microbial responses to mineralization. $\mathrm{NaCl}$ is an influencing factor that can decrease the amount of secondary metabolites (Huang et al. 2011). Mucor circinelloides did not produce acid, and its growth was diminished distinctly by $\mathrm{NaCl}$. The species most resistant to $\mathrm{NaCl}$ and $\mathrm{MgCl}_{2}$ appears to be $T$. diversus. This species was the most common fungal strain isolated from the cave rocks.

Wallemia ichthyophaga is the most halotolerant known fungus (Zajc et al. 2014). Used by us, W. mellicola has a halotolerance of 4-24 \% NaCl (Jančič et al. 2015). The colony diameter of W. mellicola changed minimally (Fig. 3). W. mellicola is an advanced halotolerant species. Also, A. pullulans var. pullulans only slightly changed its colony diameter. The species is also known for its halotolerance. However, our strains appeared sensitive to high concentrations of $\mathrm{NaCl}$. Despite the negative influence of salinity on acid production, we suppose that some fungal strains (i.e., Talaromyces diversus) can be recognized as active agents in carbonte dissolution. These halotolerant fungi can be good competitors on rocks in saline environments. Fungi identified here play a role in transforming the mineral environment of the cave. 


\section{Conclusion}

Anchialine caves have reduced food resources and low microbial diversity (see Culver and Sket, 2000). Ours is the first report of fungal diversity in anchialine caves. These caves can be a kind of 'refugium' for preservation of these unique halotolerant microorganisms.

\section{Acknowledgements}

Financial support was provided by the W. Szafer Institute of Botany of the Polish Academy of Sciences through its statutory fund. Financial support under Projects No. POIR.01.01.01-00-1254/15-00 were provided by the Ministry of Science and Higher Education (Poland). We thank the reviewers for critically reviewing the paper.

\section{References}

Barton, H.A., 2006, Introduction to cave microbiology: a review for the non-specialist: Journal of Cave and Karst Studies, v. 68, no. 2 , p. 43-52.

Barton, H.A., and Northup, D.E., 2007, Geomicrobiology in cave environments: past, current and future perspectives: Journal of Cave and Karst Studies, v. 69 , no. 1, p. 63-178.

Bensch, K., Groenewald, J.Z., Dijksterhuis, J., Starik-Willemse, M., Andersen, B., Shin, H-D., Dugan, F.M., Schroers, H-J., Braun, U., and Crous P.W., 2010, Species and ecological diversity within the Cladosporium cladosporioides complex (Davidiellaceae, Capnodiales): Studies in Mycology, v. 67, p. 1-94. https://doi.org/10.3114/sim.2010.67.01.

Bensch, K., Braun, U., Groenewald, J.Z., and Crous, P.W., 2012, The genus Cladosporium: Studies in Mycology, v. 72, p. 1-401. https://doi. org/10.3114/sim0003.

Bognar, A., 2001, Geomorphological regionalization of Croatia: Acta Geographica Croatica v. 34, p. 7-29.

Burford, E.P., Kierans, M., and Gadd, G.M., 2003, Geomycology: fungi in mineral substrata: Mycologist, v. 17 no. 3, p. 98-107. https://doi. org/10.1017/S0269915X03003112.

Cantrell, S.A., Casillas-Martinez, L., and Molina, M., 2006, Characterization of fungi from hypersaline environments of solar salterns using morphological and molecular techniques: Mycological Research, v. 110, p. 962-970. doi:10.1016/j.mycres.2006.06.05.

Culver, D.C., and Sket, B., 2000, Hot spots for subterranean biodiversity in caves and wells: Journal of Cave and Karst Studies, v. 62, no. 1, p. 11-17.

Duplančić, L.T., Ujević, T., and Čala, M., 2004, Coastline lengths and areas of islands in the Croatian part of the Adriatic Sea determined from the topographic maps at the scale of 1: 25 000: Geoadria, v. 9, no. 1, p. 5-32.

Dzaja, K., 2003, Geomorgoloske znacajke Dugog Otoka [Geomorphologic characters of Dugi Otok]: Geoadria, v. 8, no. 2, p. 5-14. https://doi. org/10.15291/geoadria.98.

Ehrlich, H.L.,1981, Geomicrobiology: New York, Marcel Dekker Inc., 393 p.

Gadd, G.M. 1993, Interactions of fungi with toxic metals: New Phytologist, v. 124, p. 25-60. https://doi.org/10.1111/j.1469-8137.1993. tb03796.x.

Gadd, G.M., and Mowll, J.L., 1985, Copper uptake by yeast-like cells, hyphae and chlamydospores of Aureobasidium pullulans: Experimental Mycology, v. 9, p. 230-240. https://doi.org/10.1016/0147-5975(85)90019-2.

Gadd, G.M., 1999, Fungal production of citric and oxalic acid: importance in metal speciation, physiology and biogeochemical processes: Advances in Microbial Physiology, v. 41, p. 47-92. https://doi.org/10.1016/S0065-2911(08)60165-4.

Ganachari, S.V., Bhat, R., Deshpande, R., and Venkataraman, A., 2012, Extracellular biosynthesis of silver nanoparticles using fungi Penicillium diversum and their antimicrobial activity studies: BioNanoScience, v. 2, no. 4, p. 316-321. https://doi.org/10.1007/s12668-012-0046-5.

Gunde-Cimerman, N., Zalar, P. and Jeram, S. 1998, Mycoflora of cave cricket Troglophilus neglectus cadavers: Mycopathologia, v. 141, no. 2, p. 111-114. https://doi.org/10.1023/A:1006947524503.

Hosono, T., Uchida, E., Suda, C., Ueno, A., and Nakagawa, T., 2006, Salt weathering of sandstone at the Ankor monuments, Cambodia: identification of the origin of salts Udine sulfur and strontium isotopes: Journal of Archeological Science, v. 33, p. 1541-1551. https://doi. org/10.1016/j.jas.2006.01.018.

Huang, J., Lu, Ch., Qian, X., Huang, Y., Zheng, Z., and Shen, Y., 2011, Effect of salinity on the growth, biological activity and secondary metabolites of some marine fungi: Acta Oceanologica Sinica, v. 30, no. 3, p. 118-123. https://doi.org/10.1007/s13131-011-0126-3.

Inf.Eurobats.Ac.19, 2004, Third Report to the National Implementation of the Agreement in Croatia 2003-2004. http://www.eurobats.org/sites/ default/files/documents/pdf/National_Reports/nat_rep_Croa_2004.pdf

Jančič, S., Nguyen, H.D.T., Frisvad, J.C., Zalar, P., Schroers, H-J., Seifert, K.A., and Gunde-Cimerman, N., 2015, The taxonomic revision of Wallemia sebi species complex: PLoS ONE, v. 10, no. 5, p. 1-25. https://doi.org/10.1371/journal.pone.0125933.

Ke, X., Wang, J., Li, M., Gu, Z., and Gong, X. 2009, First report of Mucor circinelloides occurring on yellow catfish (Pelteobagrus fulvidraco) from China: FEMS Microbiology Letters, v. 302, no. 2, p. 144-150. https://https://doi.org/10.1111/j.1574-6968.2009.01841.x.

Lübbehüsen, T.L., Nielsen, J., and Mclntyre, M., 2003, Morphology and physiology of the dimorphic fungus Mucor circinelloides (syn. M. racemosus) during anaerobic growth: Mycological Research, v. 107, p. 223-230. https://doi.org/10.1017/S0953756203007299.

Marjanac, T., and Marjanac, A., 2007, Sequence stratigraphy of Eocene incised valley clastics and associated sediments, Island of Rab, northern Adriatic Sea, Croatia: Facies, v. 53, no. 4, p. 493-508. https://doi.org/10.1007/s10347-007-0120-6.

Masuma, R., Yamaguchi, Y., Noumi, M., Ōmura S., and Namikoshi M., 2001, Effect of sea water concentration on hyphal growth and antimicrobial metabolite production in marine fungi: Mycoscience, v. 42, p. 455-459. https://doi.org/10.1007/BF02464342.

Michailides, T.J., 1991, Characterization and comparative studies of Mucor isolates from stone fruits from California and Chile: Plant Diseases, v. 75, p. 373-380. https://doi.org/10.1094/PD-75-0373.

Nováková, A., 2009, Microscopic fungi isolated from the Domica Cave system (Slovak Karst National Park, Slovakia): International Journal of Speleology, v. 38, no. 1, p. 71-82. https://doi.org/10.5038/1827-806X.38.1.8.

Nováková, A., Šimonoičová, A., and Kubátová, A., 2012, List of cultivable microfungi recorded from soil related substrata and underground environment of the Czech and Slovak Republic: Mycotaxon, v. 119, p. 1-189.

Ogórek, R., Lejman, A., and Matkowski,, K., 2014. Influence of the external environment on airborne fungi isolated from a cave: Polish Journal of Environmental Studies, v. 23, no. 2, p. 435-440.

Ogórek, R., Pusz, W., Lejman A., and Uklańska-Pusz, C., 2013, Microclimate effects on number and distribution of fungi in the Włodarz un- 
derground complex in the Owl Mountains (Góry Sowie), Poland: Journal of Cave and Karst Studies, v. 76, no. 2, p. 146-153, https://doi. org/10.4311/2013MB0123.

Owczarek-Kościelniak, M., Chlebicki, A., and Sterflinger, K., 2016, Aureobasidium pullulans from Juncus trifidus L. roots: Phytotaxa, v. 266 , no. 2, p. 155-124. https://doi.org/10.11646/phytotaxa.266.2.6.

Pavlinič, I., Dakovič, M., and Turtkovič, N., 2010, The Atlas of Croatian Bats: Part 1, Natura Croatica, v. 19, no. 2, p. 1-295.

Perica, D., Marjanac, T., Anicic, B., Mrak, I., and Juarcic, M., 2004, Small karst features (karren) of Dugi Otok Island and Kornati archipelgo coastal karst (Croatia): Acta Carsologica, v. 33, no. 1, p. 117-130.

Pikelj, K., and Juračić, M., 2013, Eastern Adriatic Coast (EAC): Geomorphology and coastal vulnerability of karstic coast: Journal of Coastal Research, v. 29, no. 4, p. 944-957, https://doi.org/10.2112/JCOASTRES-D-12-00136.1.

Pohlman, J.W., Iliffe, T.W., and Cifuentes, L.A., 1997, A stable isotope study of organic cycling and the ecology of an anchialine cave ecosystem: Marine Ecology Progress Series, v. 155, p. 17-27, https://doi.org/10.3354/meps155017.

Schipper, M.A.A., 1976, On Mucor circinelloides, Mucor racemosus and related species: Studies in Mycology v. 12, p. 1-40.

Schipper, M.A.A., 1984, A revision of the genus Rhizopus. I. Rhizopus stolonifer-group and Rhizopus oryzae: Studies in Mycology, v. 25, p. 1-19.

Speakman, H.B., Gee, A.H., and Luck, J.M., 1928, The influence of sodium chloride on the growth and metabolism of yeast: Journal of Bacteriology, v. 15 no. 5 , p. 319-340.

Sponga, F., Cavaletti, L., Lazzarini, A., Borghi, A., Ciciliato, I., Losi, D., and Marinelli, F., 1999, Biodiversity and potentials of marine-derived microorganisms: Journal of Biotechnology v. 70, no. 1-3, p. 65-69. https://doi.org/10.1016/S0168-1656(99)00059-0.

Sterflinger, K., 2000, Fungi as geologic agents: Geomicrobiology Journal, v. 17, p. 97-124. https://doi.org/10.1080/01490450050023791.

Stewart, N.J., Munday, B.L.,, and Hawkesford T., 1999, Isolation of Mucor circinelloides from a case of ulcerative mycosis of platypus (Ornithorhynchus anatinus), and a comparison of the response of Mucor circinelloides and Mucor amphibiorum to different culture temperatures: Medical Mycology, v. 37, no. 3, p. 201-206. https://doi.org/10.1046/j.1365-280X.1999.00221.x.

Surić, M., Lončarić, R., and Lončar, N., 2010, Submerged caves of Croatia - distribution, classification and origin: Environmental Earth Sciences, v. 61, p. 1473-1480. https://doi.org/10.1007/s12665-010-0463-0.

Tobin, J.M., 2001, Fungal metal biosorption: in Gadd, G.M. ed.. Fungi in Bioremediation: Cambridge, Cambridge University Press, p. $424-444$. https://doi.org/10.1017/CBO9780511541780.016.

Vandel, A. 1965, Biospeleology: The Biology of Cavernicolous Animals: Oxford-Frankfurt, Pergamon Press, 524 p. https://doi.org/10.1016/B9780-08-010242-9.50027-X.

Vanderwolf, K.J., Malloch, D., McAlpine, D.F., and Forbes, G.J., 2013, A world review of fungi, yeasts, and slime molds in caves: International Journal of Speleology, v. 42, no. 1, p. 77-96. https://doi.org/10.5038/1827-806X.42.1.9.

Verrecchia, E.P., 2000, Fungi and sediments: in Riding R.E., and Awramik S.P., eds., Microbial Sediments: Berlin, Heidelberg, Springer-Verlag, p. 68-75. https://doi.org/10.1007/978-3-662-04036-2_9.

Vlahović, I., Tisljar, J., Velic, I., and Maticec, D., 2005, Evolution of the Adriatic Carbonate Platform: Paleogeography, main events and depositional dynamics: Palaeogeography, Palaeoclimatology, Palaeoecology, v. 220, p. 333-360. https://doi.org/10.1016/j.palaeo.2005.01.011.

Yilmaz, N., Visagie, C.M., Houbraken, J., Frisvad, J.C. and Samson, R.A., 2014, Polyphasic taxonomy of the genus Talaromyces: Studies in Mycology, v. 78, p. 175-341, https://doi.org/10.1016/j.simyco.2014.08.001.

Zajc, J., Džeroski, S., Kocev, D., Oren, A., Sonjak, S., Tkavc, R., and Gunde-Cimerman N., 2014, Chaophilic or chaotolerant fungi: an new category of extremophiles?: Frontiers in Microbiology, v. 5, no. 708, p. 1-15.

https://doi.org/10.3389/fmicb.2014.00708.

Zalar, P., Hoog, G.S., Schroers, H-J., Crous, P.W., Groenewald, J.Z. and Gunde-Cimerman, N., 2007, Phylogeny and ecology of the ubiquitous saprobe Cladosporium sphaerospermum, with descriptions of seven new species from hypersaline environments: Studies in Mycology, v. 58 , p. 157-183. https://doi.org/10.3114/sim.2007.58.06. 